DOI: 10.15393/j9.art.2020.8522

УДК 821.161.1.09“18”

В. А. Воропаев

Московский государственный университет им. М. В. Ломоносова

(Москва, Российская Федерация)

voropaevvl@bk.ru

\title{
Миросозерцание и поэтика Н. В. Гоголя в критике Русской эмиграции (1921-2018)*
}

Аннотация. Русская эмиграция уделила Н. В. Гоголю исключительное внимание (сравнимое, может быть, только с А. С. Пушкиным и Ф. М. Достоевским). Тематика и проблематика гоголеведческих исследований, написанных в Русском зарубежье, чрезвычайно разнообразна. При этом преимущественное внимание в них уделено поэтике произведений Гоголя и религиозному миросозерцанию писателя. Гоголь и Достоевский, Гоголь и христианское отношение к смеху, проблема пошлости в творчестве Гоголя, поэтика страха в повести Гоголя «Вий», театральная эстетика Гоголя, эволюция Гоголя как писателя, ритм прозы Гоголя, проблема человека у Гоголя - все эти вопросы поэтики Гоголя впервые поставлены в критике Русской эмиграции и получили дальнейшее развитие в отечественной науке. Благодаря работам К. В. Мочульского, В. В. Зеньковского, Д. М. Чижевского, С. Л. Франка впервые были опровергнуты укоренившиеся в литературоведении ложные концепции личности Гоголя. Эмигрантское гоголеведение органично вошло в научный оборот современного литературоведения. Несмотря на ограниченную источниковедческую базу, работы авторов Русского зарубежья знаменовали собой новый, важнейший этап в освоении творческого наследия Гоголя.

Ключевые слова: Гоголь, религиозное миросозерцание, биография, поэтика, интерпретация, комическое, ужасное, ритмическая организация текста, мотив, интертекст, альбомная проза

Об авторе: Воропаев Владимир Алексеевич - доктор филологических наук, профессор кафедры истории русской литературы, Московский государственный университет им. М. В. Ломоносова (Ленинские горы, д. 1, г. Москва, Российская Федерация, 119991)

Дата поступления: 20.07 .2020

Дата публикации: 30.10 .2020

Для цитирования: Воропаев В. А. Миросозерцание и поэтика Н. В. Гоголя в критике Русской эмиграции (1921-2018) // Проблемы исторической поэтики. —2020. - Т. 18. — № 4. — C. 138-163. DOI: 10.15393/j9.art.2020.8522 
$\mathrm{D}$ усская эмиграция уделила Н. В. Гоголю исключительное внимание (сравнимое, может быть, только с А. С. Пушкиным и Ф. М. Достоевским). В эмиграции не раз издавались как отдельные произведения Гоголя, так и собрания его сочинений. Отметим лишь некоторые из них. В 1921 г. в Берлине в издательстве "Слово» вышло в свет Полное собрание сочинений писателя в 10 томах с предисловием Н. Яковлева ${ }^{1}$. В 1922 г. берлинское издательство «Геликон», продолжившее свою деятельность, начатую в России, напечатало повесть Гоголя «Нос» с рисунками художника-графика В. Н. Масютина (издание отличается особой тщательностью полиграфического исполнения и было репринтно переиздано в 1989 г.) $)^{2}$. В 1952 г. издательство им. Чехова в Нью-Йорке выпустило «петербургские» повести Гоголя с предисловием В. В. Набокова ${ }^{3}$. В том же году иждивением Свято-Троицкого монастыря в Джорданвилле издана книга Гоголя «Размышления о Божественной Литургии» ${ }^{4}$ Это было первое отдельное издание за границей сочинения Гоголя, ставшего для него итоговым и занимающего особое место в его творчестве. В Советской России оно не печаталось даже в академическом Полном собрании сочинений писателя «как не имеющее прямого отношения к литературной деятельности Гоголя и представляющее узко биографическое значение...» [Гоголь, 1952: 743].

Из коллективных трудов о Гоголе, изданных в Русском зарубежье и не утративших своего значения и поныне, следует назвать сборник «Великий россиянин», выпущенный в свет Российской колонией в Аргентине к 100-летней годовщине со дня смерти Гоголя (см.: [Сборник статей, посвященных памяти Н. В. Гоголя...]) и 17 том Записок русской академической группы в США, приуроченный к 175-летию со дня рождения Гоголя (см.: [Записки русской академической группы в США]). В сборник, вышедший в Аргентине, включены статьи митрополита Анастасия (Грибановского), архимандрита Константина (Зайцева), И. М. Андреева, Б. Башилова, Ф. В. Вербицкого, Н. Н. Воейкова, М. В. Зызыкина, Н. Д. Тальберга, Н. Федорова и др. 
Архимандрит (в ту пору игумен) Константин (Зайцев) в философском эссе «Гоголь как учитель жизни» поставил проблему христианского отношения к смеху. «Смеха не слыхали окружавшие Спасителя. Можно ли представить себе смеющейся Деву Марию?» - вопрошает автор [Константин, игумен (Зайцев): 35]. «Остережемся, однако, этот запрет смеха переносить из мира духа в область явлений душевных». В будничной жизни смех живет в разных качествах. «Когда человек предает себя жизни духа - «умирает в нем смех» [Константин, игумен (Зайцев): 36]. Искусство - дело душевное. Гоголь «пронизан душевностью». В его распоряжении два основных средства - «фантастика и смех». Порываясь к духовному, Гоголь ломает «рамки искусства, не вмещаясь в них» [Константин, игумен (Зайцев): 36]. «Беззаботен гоголевский смех, беспечна гоголевская фантастика. Но как много уже содержат в себе и как многому учат даже и этот смех и эта фантастика» [Константин, игумен (Зайцев): 38]. В плане душевном гоголевский смех уже отчасти обладает «великой религиозно-моральной силой, неизменно бо́льшей, чем гоголевская фантастика» [Константин, игумен (Зайцев): 38-39].

Христианское отношение Гоголя к смеху и сегодня остается одной из дискуссионных проблем его поэтики. В Православии преобладает отношение к смеху как явлению греховному. Святость допускает аскетическую суровость и благостную улыбку, но исключает смех. «...Предание, согласно которому Христос никогда не смеялся, с точки зрения философии смеха представляется достаточно логичным и убедительным. В точке абсолютной свободы смех невозможен, ибо излищен» [Аверинцев: 9]. Смех уходит из поздних сочинений Гоголя. При всем том писатель позитивно оценивал смех и, очевидно, не считал его несовместимым с христианской позицией. В своих художественных произведениях Гогольхристианин смеется сострадательно. Он высмеивает грех, но сочувствует грешнику. Без этого внутреннего содержания смех становится осуждением. В этом, в частности, проявилась органическая связь творчества Гоголя с народной культурой. Недаром пословица назидает: «С грехом борись, а с грешником мирись». Эта важная особенность отношения Гоголя к смеху 
была отмечена его современниками. «На какой бы низкой степени ни стояло лицо у Гоголя, - писал К. С. Аксаков, - вы всегда признаете в нем человека, своего брата, созданного по образу и подобию Божиему» [Аксаков: 82].

В сборнике, изданном в Аргентине, также опубликована (впервые за пределами России) стихотворная молитва Гоголя ко Пресвятой Богородице, широко распространенная в рукописной традиции под названием «гоголевская молитва» и ставшая едва ли не самым известным его произведением в славянских (и не только) странах (см.: [Гоголь, 2009-2010, т. 6: 415, 736-738], [Стихотворный альманах...], [Воропаев, 2016 а]).

В 17-й том «Записок русской академической группы в США» вошли работы на русском и английском языках, посвященные различным аспектам поэтики Гоголя. Так, Н. Жернакова сопоставила две редакции повести «Портрет» (1835 и 1842 гг.) в аспекте эволюции эстетических воззрений Гоголя. Автор полагает, что во второй редакции «общее направление повести теряет свой фантастично-романтический характер и приобретает черты более тонкого психологического анализа» [Жернакова: 28]. По мнению исследователя, ряд художественных образов в повести, скорее всего, почерпнут писателем из собственной жизни.

В статье 3. Юрьевой и В. Филипп «О поэтике страха в повести Гоголя “Вий”» анализируются эстетические категории «страх» и «страшное», которые, как считают исследователи, «были в центре творческого внимания Гоголя» [Юрьева, Филипп: 3]. В этом отношении особо примечательна повесть «Вий», которая «как бы воплощает и символизирует страх, становится почти его синонимом» [Юрьева, Филипп: 4]. В статье рассмотрена «лексика страха» и связанные с ней синтаксические и стилистические приемы, использованные Гоголем.

Н. Каухчишвили проанализировала некоторые художественные приемы у Гоголя, «на которых строится стилистическая и композиционная выразительность авторской речи». Такими приемами, считает исследователь, Гоголь «достигает необычной внутренней свободы и независимости от традиционных норм» [Каухчишвили: 50]. 
В томе «Записок» также помещены статьи В. Терраса «"Шинель” Гоголя в критике молодого Достоевского» (см.: [Террас], Н. Натовой «Михаил Булгаков и Гоголь: Опыт сопоставительного анализа» (см.: [Натова] и В. Крупича «Гоголь и Аполлон Григорьев» (см.: [Крупич]. Здесь же Н. П. Полторацким впервые напечатано изложение лекции известного русского философа И. А. Ильина на немецком языке «Gogol der grosse russische Satyriker, Romantiker und Lebensphilosoph», прочитанной в 1944 г. в Цюрихе (см.: [Полторацкий, 1984; Ильин]).

Русскими эмигрантами написано несколько диссертаций о Гоголе. В 1933 г. В. М. Горлин в Берлине защитил диссертацию «N. V. Gogol und E. Th. A. Hoffman», вышедшую отдельной книгой (см.: [Gorlin]). Исследователь первым заговорил о полемике Гоголя с европейским романтизмом. Отмечая замствования из поэтики Гофмана, Горлин указывает на самобытность писательской манеры русского классика. Эта проблема получила дальнейшее развитие в отечественном литературоведении (см., напр.: [Ботникова]).

Книгу высоко оценил В. В. Вейдле: «...превосходная работа молодого русского историка литературы <...> заново рассматривает вот уже сто лет существующий вопрос о влиянии Гофмана на Гоголя» [Вейдле: 464]. Горлин очень хорошо показал, как Гоголь «постепенно отходит от Гофмана - возвращается к самому себе» [Вейдле: 464]. Впоследствии иследователь, по всей видимости, продолжил свои гоголеведческие штудии. По словам А. В. Бахраха, он даже пытался реконструировать задуманную Гоголем комедию «Владимир третьей степени», «работая над этим с той тщательностью, с какой музейные реставраторы стараются собрать воедино уцелевшие черепки какой-нибудь античной вазы» [Бахрах: 353]. Об этой работе Горлина сведений не сохранилось: вероятно, она не была завершена. Реконструкция замысла незаконченной комедии Гоголя по-прежнему остается одной из актуальных проблем его поэтики. На основе написанных сцен «Владимира третьей степени» им созданы драматические отрывки «Утро делового человека», «Тяжба», «Лакейская» и «Отрывок» (см.: [Гоголь, 2009-2010, т. 7: 131-137, 672-674]; см. также: [Захаров], [Бельтраме]). 
Широкую известность в Русском зарубежье получило изданное в 1953 г. Институтом Восточной Европы в Западном Берлине диссертационное исследование на немецком языке В. М. Сечкарева (см.: [Setschkareff]), переведенное в 1965 г. на английский язык (см.: [Setchkarev]). Жизнь и творчество Гоголя исследователь рассматривает в религиозном и психопатологическом плане в русле декадентских толкований (Д. С. Мережковский, В. В. Розанов). Повесть «Тарас Бульба» оценивается им как проявление «сентиментального патриотизма» и характеризуется как «переведенная в новое время “Илиада", но без ее человеческого дыхания» [цит. по: Шлаин: 62, 77]).

В 1955 г. под руководством Сечкарева 3. Юрьева защитила диссертацию «Gogol as Interpreted by the Russian Symbolists» (см.: [Yurieff]). Определенную научную ценность имеет приложение к диссертации «Отражение новой интерпретации Гоголя в иллюстрациях и в театральных постановках». (Оценку работы с позиций современной науки см.: [Сугай: 10-11].)

Из неизвестных ранее автографов Гоголя, опубликованных в эмиграции, обращают на себя внимание два. В 1925 г. М. Л. Гофман в статье «Последние дни Гоголя (новые материалы)» по рукописям Онегинского архива в Париже напечатал (без атрибуции текста) несколько разрозненных фрагментов, в том числе выписки Гоголя из «Лествицы» преподобного Иоанна Лествичника, игумена Синайской горы (см.: [Гофман], [Гоголь, 2009-2010, т. 6: 297-299, 663-668]). Сохранились свидетельства, что Гоголь внимательно изучал «Лествицу» и делал из нее подробные выписки. Образ лестницы, соединяющей землю с небом, - один из любимейших у Гоголя. Он встречается уже в одном из самых ранних его произведений - в повести «Майская ночь, или Утопленница» (1829). Этот же образ находим и в заключительной главе «Светлое Воскресенье» из «Выбранных мест из переписки с друзьями» - последнем напечатанном при жизни произведении Гоголя (см. подробнее: [Воропаев, 2018]). В данной связи уместно привести свидетельство Т. И. Филиппова в письме к К. Н. Леонтьеву из СанктПетербурга от 22 февраля 1888 г.: «С высоты “Лествицы”, которая особенно его (Гоголя. - В. В.) восхищала и которую он переписал своею рукой, желая глубже запечатлеть в своей 
памяти ее божественное содержание, все его произведения, в особенности комические, естественно должны были представиться в их относительном ничтожестве» [Пророки Византизма: 492-493].

В 1972 г. Р. Якобсон и Б. Арутюнова опубликовали запись Гоголя в альбом М. А. Власовой («Как ни глуп Индейский петух...») (см.: [Jakobson, Aroutunova], [Гоголь, 2009-2010, т. 9: 474, 843-844]). Авторы применили комплексный подход к исследованию новонайденного текста Гоголя, охватывающий все важнейшие аспекты поэтики. По их мнению, данная альбомная запись является «шедевром точного, изысканно отточенного, ясно организованного и гармоничного с точки зрения архитектоники, причудливого словесного творчества» (перевод с англ. М. С. Антоновой [Антонова, 2019b: 34]).

Следует отметить, что альбомная проза Гоголя до последнего времени не изучалась в литературоведении, если не считать публикации его записей в рукописных альбомах современников и комментарии к ним в Полном собрании сочинений и писем Гоголя в 17 томах (см.: [Гоголь, 2009-2010, т. 9: 473-475, 842-846]). В настоящее время на кафедре истории русской литературы Московского государственного университета им. М. В. Ломоносова представлена к защите диссертация М. С. Антоновой, где данная проблема впервые поставлена в контекст альбомной культуры первой половины XIX в. Особое внимание в работе уделено изучению альбома М. А. Власовой, сестры княгини 3. А. Волконской, архив которой ныне находится в Рукописном отделе библиотеки Гарварда (см.: [Антонова, 2019a; 2019b]).

Из всего многообразия литературы о Гоголе, созданной русскими эмигрантами первой волны, наибольшую известность получили книги К. В. Мочульского «Духовный путь Гоголя» (1934), В. В. Набокова «Николай Гоголь» (1944) и протопресвитера В. В. Зеньковского ${ }^{5}$ «Н. В. Гоголь» (1961). Они во многом определили гоголеведческую мысль не только на Западе, но и в России. Наряду с этими исследованиями есть целый ряд менее объемных трудов, которые также внесли свой вклад в изучение поэтики и религиозного миросозерцания великого русского писателя. Это работы вышеупомянутых 
К. В. Мочульского и В. В. Зеньковского, а также Ю. И. Айхенвальда, Н. А. Бердяева, П. М. Бицилли, В. В. Вейдле, В. Н. Ильина, С. Л. Франка, Д. М. Чижевского. Назовем еще публикации Ю. П. Анненкова, А. Ф. Бема, Г. И. Газданова, Б. К. Зайцева, Г. А. Мейера, Р. В. Плетнева, А. М. Ремизова, Н. И. Ульянова, В. Ф. Ходасевича - статьи и очерки, в которых имеются существенные для науки о Гоголе наблюдения.

Гоголиана Русской эмиграции обследована далеко не полностью. Вместе с тем в современном литературоведении существует ряд специальных работ и даже диссертаций, посвященных осмыслению творческого наследия Гоголя в критике Русского зарубежья (см.: [Моисеев], [Евфимий (Моисеев), иеромонах], [Евтихиева, 1999, 2001], [Воропаев, 2002, 2003, 2006], [Злочевская, 2005], [Гольденберг, 2006, 2010], [Гусев], [Ермишин]).

В 2005 г. в Доме Русского зарубежья в Москве в рамках ежегодных Гоголевских чтений прошла международная научная конференция «Н. В. Гоголь и Русское зарубежье». По материалам конференции издан сборник статей, освещающих различные аспекты рецепции Гоголя в культуре Зарубежной России: Гоголь в поэзии Русской эмиграции; эсхатологическая проблематика творчества Гоголя; поэтика Гоголя в исследованиях А. Ф. Бема, П. М. Бицилли, В. В. Зеньковского, В. Н. Ильина, архимандрита Константина (Зайцева), Г. А. Мейера, К. В. Мочульского, Р. В. Плетнева, Г. В. Флоровского, С. Л. Франка и др. (см.: [Н. В. Гоголь и Русское зарубежье]).

Тематика и проблематика гоголеведческих исследований, написанных в эмиграции, чрезвычайно разнообразна. При этом преимущественное внимание в них уделено поэтике произведений Гоголя и религиозному миросозерцанию писателя. Гоголь и Достоевский (А. Ф. Бем, Д. М. Чижевский, В. Террас), Гоголь и христианское отношение к смеху (архимандрит Константин (Зайцев)), проблема пошлости в творчестве Гоголя (В. В. Набоков, В. В. Зеньковский), поэтика страха в повести Гоголя «Вий» (3. Юрьева и В. Филипп), театральная эстетика Гоголя (Ю. П. Анненков, В. Ф. Ходасевич), эволюция Гоголя как писателя (Б. К. Зайцев), ритм прозы 
Гоголя (Р. В. Плетнев), проблема человека у Гоголя (П. М. Бицилли) - все эти вопросы поэтики Гоголя впервые поставлены в критике Русской эмиграции и получили дальнейшее развитие в отечественной науке.

Во многом благодаря работам К. В. Мочульского, В. В. Зеньковского, Д. М. Чижевского, С. Л. Франка были опровергнуты укоренившиеся в литературоведении ложные концепции личности Гоголя. Несмотря на некоторые спорные суждения, встречающиеся в исследованиях этих авторов, они не утратили своего значения для гоголеведения и по сей день.

Вместе с тем нельзя не заметить вторичность и поверхностность большинства эмигрантских работ о Гоголе. Одна из причин этого заключается в том, что почти все писавшие о Гоголе в Русском зарубежье в качестве одного из основных источников использовали книгу В. В. Вересаева «Гоголь в жизни», которая при всех своих достоинствах не содержит документальных свидетельств в необходимой полноте. Вышедшая в 1933 г. в издательстве «Academia», она значительно облегчила труд биографов и исследователей творчества Гоголя, собрав под одной обложкой многие важные (и нередко труднодоступные, разбросанные по периодике) источники. «Гоголь в жизни» Вересаева - своеобразная биографическая летопись, составленная из документов и мемуарных свидетельств современников. Книга оказалась востребованной в эмигрантской среде. По словам одного из ее рецензентов, сборник составлен так мастерски и вдумчиво, что «интереснее и умнее многих биографий» [Словцов] (см. также: [Полнер]). Можно смело утверждать, что чего нет в книге Вересаева, нет в работах о Гоголе авторов Зарубежной России.

Между тем в последние годы в гоголеведении значительно обновилась источниковедческая база. Вышли в свет новые биографические труды, Летопись жизни и творчества Гоголя в семи томах, систематический свод мемуаров в трех томах. Опубликованы очередные тома нового академического издания (ИМЛИ РАН), издано Полное собрание сочинений и писем Гоголя в 17 томах, где впервые в полном объеме напечатана переписка Гоголя (включая ответы его адресатов). С выходом этих изданий изучение гоголевского наследия 
приобретает принципиально новый характер, дает возможность по-новому, с научной объективностью оценить вклад Русской эмиграции в науку о Гоголе.

Труды исследователей-эмигрантов первой волны со всей очевидностью показали, что Гоголь не только гениальный художник, но и выдающийся религиозный мыслитель. Эта сторона творческого наследия писателя в советскую эпоху, как известно, не изучалась по идеологическим соображениям.

С. Л. Франк в статье на немецком языке «Nicolaj Gogol als religioser Geist» назвал Гоголя «первым представителем глубокого и трагического религиозного стремления, которым проникнута русская литература» [Франк: 311]. Статья долго оставалась незамеченной в гоголеведении, между тем в ней предвосхищены многие идеи о характере религиозного миросозерцания Гоголя, высказанные впоследствии другими исследователями. В частности, философ отмечал, что в «Выбранных местах из переписки с друзьями» Гоголь выдвинул идеал воцерковления русской жизни - идеал, до сих пор глубоко значимый для России (см.: [Франк: 307]).

Современные исследователи часто цитируют ставшие хрестоматийными слова К. В. Мочульского о том, что Гоголю «было суждено круто повернуть всю русскую литературу от эстетики к религии, сдвинуть ее с пути Пушкина на путь Достоевского» [Мочульский: 37]. Широко известны работы В. В. Зеньковского, в которых утверждается, что Гоголь вплотную подошел к основным темам русской религиозной философии. По словам философа, «Гоголя можно без преувеличения назвать пророком православной культуры. В этом выразилось его участие в развитии русской философской мысли...» [Зеньковский: 186]. Во многом остается справедливым замечание этого крупнейшего историка русской религиозной философии, что время «для исторической справедливой оценки Гоголя как мыслителя все еще не настало» [Зеньковский: 189].

При всех несомненных заслугах авторов Русской эмиграции в изучении религиозного миросозерцания Гоголя нельзя не заметить, что многие важные вопросы, связанные с духовным 
наследием писателя, ими не были поставлены. Опубликованные уже в наше время тетради выписок Гоголя из творений святых отцов и богослужебных книг, маргиналии на полях принадлежавшей ему Библии заставляют пересмотреть многие традиционные представления о духовном облике писателя, открывают новое в его творческих устремлениях, помогают понять сокровенный смысл его произведений (см.: [Гоголь, 2009-2010, т. 9: 7-419, 767-840, 941-945], см. также: [Воропаев, 2017, 2018, 2020]). Изучение эсхатологической проблематики творческого наследия Гоголя, начало которому положили работы К. В. Мочульского, В. В. Зеньковского, Д. И. Чижевского, Н. И. Ульянова, также невозможно без обращения к новооткрытым материалам. Эсхатология Гоголя укоренена в апокалиптике Нового Завета и святоотеческом наследии. Карандашные пометы на полях принадлежавшей ему Библии свидетельствуют о его пристальном и неизменном интересе к эсхатологическим вопросам Священного Писания (см.: [Воропаев, 2016b], [Виноградов, 2019]).

В книге протоиерея Г. В. Флоровского «Пути русского богословия» (1937) предпринята попытка охарактеризовать основные темы религиозных исканий Гоголя. Суть своих размышлений богослов формулирует следующим образом: «Религиозный путь Гоголя был труден, в своих изгибах и надломах он не объяснен и вряд ли объясним» [Флоровский: 338]. Говоря о «Размышлениях о Божественной Литургии», Флоровский утверждает, что «Гоголь остается все время в кругу довольно неопределенного пиэтизма». В этой книге, по его словам, самому Гоголю принадлежит только «стиль трогательной и искренней чувствительности» [Флоровский: 342] ${ }^{6}$. Вывод исследователя неутешителен: «В творчестве Гоголя проблема христианской культуры была показана с ее утопической стороны, в ее опасностях и неувязках, как некое искушение» [Флоровский: 344].

Труд известного религиозного философа Русской эмиграции вызвал серьезные возражения современных литературоведов. Так, И. А. Есаулов не нашел в работе Флоровского «ни тонкого, собственно богословского анализа гоголевского творчества, ни, тем более, глубокого литературоведческого 
описания гоголевских произведений» [Есаулов: 226-227]. Причину этого исследователь видит в том, что «само русское богословие как таковое» по отношению к произведениям светских авторов и во времена Флоровского, и в наше время «все еще не выработало адекватного своему предмету понятийного аппарата» [Есаулов: 227].

По-иному оценивают последнюю книгу Гоголя современные богословы. По наблюдению протоиерея П. В. Хондзинского, декана богословского факультета Православного Свято-Тихоновского гуманитарного университета, «гоголевские "Размышления” не являются простой компиляцией существующих толкований, а содержат оригинальные богословские идеи автора» [Хондзинский, 2016: 237]; «в своем переживании литургии как центра церковно-общественной жизни Гоголь в своем роде уникален и может быть назван предтечей того “евхаристического возрождения", которое приходит в русскую традицию в конце XIX - начале XX в.» [Хондзинский, 2016: 238] (см. также: [Хондзинский, 2017]).

Гоголевское разъяснение Литургии, в основание которого положено святоотеческое учение и в котором органично сочетаются богословская и художественная (главным образом стилистическая) стороны, представляет собой совершенно оригинальное произведение и один из лучших образцов русской духовной прозы (см.: [Воропаев, 2019]). В этой связи сошлемся на мнение Б. К. Зайцева об этом сочинении Гоголя: «Не берусь судить о нем со стороны богословской. Но как поэзия и литература это прекрасно, полно истинной гармонии, духовности и под скромным обликом описания церковной службы дает в самом напеве своем, в прозрачности, внутренней просветленности как бы отражение в словесности духа Литургии. В “Размышлениях" Гоголь поступил как музыкант, в зрелом возрасте перешедший от сочинения светской музыки к созданию церковной» [Зайцев: 284-285].

Подводя итоги сказанному, еще раз подчеркнем, что эмигрантское гоголеведение органично вошло в научный оборот современного литературоведения. Несмотря на ограниченную источниковедческую базу, работы авторов Русского зарубежья знаменовали собой новый, важнейший этап в освоении творческого наследия Гоголя. 


\section{Примечания}

* Исследование выполнено при финансовой поддержке Российского фонда фундаментальных исследований (РФФИ) в рамках научного проекта № 19-112-50197.

1 См.: Гоголь Н. В. Полн. собр. соч.: в 10 т. / предисл. Н. Яковлева. [Берлин]: Слово, 1921.

2 См.: Гоголь Н. В. Нос: повесть / рис. В. Масютина. М.; Берлин: Геликон, 1922. 69 с. Переиздано: Гоголь Н. В. Нос / рис. В. Н. Масютина; послесл. В. Ф. Муленковой. М.: Книга, 1989. Репринтное воспроизведение издания 1922 г. с иллюстрациями В. Н. Масютина. 72 с. (Книжные редкости. Библиотека репринтных изданий).

3 См.: Гоголь Н. В. Повести / предисл. В. В. Набокова-Сирина. Нью-Йорк: Изд-во им. Чехова, 1952. VII, 257 с.

4 См.: Гоголь Н. В. Размышления о Божественной Литургии. Джорданвилль: Изд-во Свято-Троицкого монастыря [Jordanville; N.Y.: Holy Trinity Monastery], 1952. 47 с. Изд. 3-e: Jordanville; N.Y., 1965.

5 В литературе В. Зеньковского часто называют протоиереем, что не совсем правильно. В 1955 г. он был возведен в сан протопресвитера. В русской церковной традиции этот сан принадлежит к особым богослужебно-иерархическим наградам, право награждения которыми принадлежит исключительно первоиерарху Поместной Православной Церкви.

6 Ср. суждение митрополита Сурожского Антония (Блума): «...его (Гоголя. - В. В.) комментарий на Литургию - слащав, беден и бесконечно хуже "Вечеров на хуторе близ Диканьки"» [Антоний Сурожский, митрополит: 331].

\section{Список литературы}

1. Аверинцев С. С. Бахтин, смех и христианская культура // М. М. Бахтин как философ. - М.: Наука, 1992. - С. 7-19.

2. Аксаков К. С. Несколько слов о поэме Гоголя: похождения Чичикова, или Мертвые души // Аксаков К. С. Эстетика и литературная критика / сост., вступ. ст., коммент. В. А. Кошелева. - М.: Искусство, 1995. С. 74-85. (История эстетики в памятниках и документах).

3. Антоний Сурожский, митрополит. Труды: в 2 кн. - 2-е изд. - М.: Практика, 2012. - Кн. 1. - 1112 с.

4. Антонова М. С. Альбомные записи Н. В. Гоголя // Мир науки, культуры, образования. - Горно-Алтайск, 2019. — № 5 (78). - С. 514-515. (а)

5. Антонова М. С. Запись Н. В. Гоголя в альбом М. А. Власовой: к проблеме датировки // Litera. - M., 2019. - № 2. - C. 31-36. (b) 
6. Бахрах А. По памяти, по записям // Новый журнал. - Нью-Йорк, 1993. — № 190/191. - С. 351-355.

7. Бельтраме Ф. Неоконченная пьеса «Владимир 3-ей степени» как своеобразная творческая лаборатория Н. В. Гоголя // Н. В. Гоголь и театр: Третьи Гоголевские чтения: сб. докладов / городская библиотека им. Н. В. Гоголя; под общ. ред. В. П. Викуловой. - М.: Кн. дом «Университет», 2004. - С. 90-100.

8. Ботникова А. Б. Гофман и Гоголь (Диалектическое восприятие романтической традиции) // Ботникова А. Б. Э. Т. А. Гофман и русская литература (первая половина XIX века): к проблеме русско-немецких литературных связей. - Воронеж: Изд-во Воронежского ун-та, 1977. C. 107-149.

9. Вейдле В. М. [Рец. на кн.: M. Gorlin. N. V. Gogol und E. Th. A. Hoffmann. O. Harrassowitz. Leipzig. 1933] // Современные записки. - Париж, 1934. - № 54. - C. 464-465.

10. Виноградов И. А. Эсхатология комедии Н. В. Гоголя «Ревизор» // Проблемы исторической поэтики. - 2019. - Т. 17. — № 4. - С. 68-90 [Электронный ресурс]. - URL: https://poetica.pro/files/redaktor_pdf/1571049477. pdf (30.05.2020). DOI: 10.15393/j9.art.2019.5801

11. Воропаев В. А. Гоголь в критике Русской эмиграции // Русская литература. - СПб., 2002. - № 3. - С. 192-211.

12. Воропаев В. А. Русская эмиграция о Н. В. Гоголе // Русская речь. - М., 2003. - № 2. - C. 16-21; № 3. - С. 11-17; № 4. - С. 10-18.

13. Воропаев В. А. Гоголь Николай Васильевич (1809-1852) // Литературная энциклопедия Русского зарубежья. 1918-1940: в 4 т. - М.: Российская политическая энциклопедия (РОССПЭН), 2006. - Т. 4: Всемирная литература и Русское зарубежье. - С. 95-117.

14. Воропаев В. А. «Умереть с пеньем на устах...» Молитва Гоголя ко Пресвятой Богородице в славянском фольклоре и литературном предании // Проблемы исторической поэтики. - Петрозаводск: Изд-во ПетрГУ, 2016. - Вып. 14. - С. 155-171 [Электронный ресурc]. - URL: https:// poetica.pro/files/redaktor_pdf/1482826798.pdf (30.05.2020). DOI: 10.15393/ j9.art.2016.3901 (a)

15. Воропаев В. А. Эсхатология Н. В. Гоголя // Язык и текст. - 2016. T. 3. — № 4. - С. 9-24 [Электронный pecypc]. — URL: http://psyjournals. ru/langpsy/2016/n4/Voropaev.shtml (30.05.2020). DOI: 10.17759/ langt.2016030402 (b)

16. Воропаев В. А. Н. В. Гоголь и святоотеческое наследие (к постановке проблемы) // Вестник Московского ун-та. Сер. 9. Филология. - М., 2017. - № 5. - C. 9-20.

17. Воропаев В. А. Лествица преподобного Иоанна Синайского в жизни и творчестве Н. В. Гоголя // Русская речь. — М., 2018. — № 6. — С. 101-108.

18. Воропаев В. А. «Размышления о Божественной Литургии» Н. В. Гоголя в свете святоотеческой традиции // «Таинство слова и образа»: к 1030-летию Крещения Руси: сб. материалов научно-богословской 
конференции / Московская Духовная академия, кафедра филологии; редкол.: проф. В. М. Кириллин, свящ. Дмитрий Барицкий (отв. ред.), иером. Далмат (Юдин). - Сергиев Посад; Переславль: Изд-во Московской Духовной академии; Издательский отдел Переславской епархии, 2019. - С. 264-279.

19. Воропаев В. А. Гоголь и «Добротолюбие» (к постановке вопроса) // Гоголь и русская духовная культура. Девятнадцатые Гоголевские чтения: сб. науч. ст. по материалам Междунар. науч. конф. / Дом Н. В. Гоголя - мемориальный музей и научная библиотека»; под общ. ред. В. П. Викуловой. - М.; Новосибирск: Новосибирский издательский дом, 2020. - С. 28-37.

20. Гоголь Н. В. Полн. собр. соч.: [в 14 т.] / Академия наук СССР. Институт русской литературы (Пушкинский Дом). - [Л.:] Изд-во АН СССР, 1952. - Т. 8: Статьи / ред. издания Н. Ф. Бельчиков, Б. В. Томашевский; подгот. текстов и коммент. О. Б. Билинкиса, Г. М. Фридлендера, Б. В. Томашевского, Л. М. Лотман. - 816 с.

21. Гоголь Н. В. Полн. собр. соч. и писем: в 17 т. (15 кн.) / сост., подгот. текстов и коммент. И. А. Виноградова, В. А. Воропаева. - М.; Киев: Изд-во Московской Патриархии, 2009-2010. - Т. 6: Выбранные места из переписки с друзьями. Духовная проза. Критика. - 744 с.; Т. 7: Юношеские опыты. Первоначальные редакции. - 816 с.; Т. 9: Выписки из творений святых отцов. Каноны и песни церковные. Словари. Записные книжки. -968 с.

22. Гольденберг А. Х. Ад и Рай Гоголя (к проблеме интерпретации творчества писателя в критике Русского Зарубежья) // Н. В. Гоголь и Русское Зарубежье: Пятые Гоголевские чтения: сб. докладов / Центральная городская библиотека - мемориальный центр «Дом Гоголя»; под общ. ред. В. П. Викуловой. - М.: Кн. дом «Университет», 2006. - С. 89-101.

23. Гольденберг А. Х. Эсхатология Гоголя как предмет критической рефлексии литературы Русского зарубежья // Гоголь и 20 век: материалы Междунар. конф., организованной докторской программой ELTE «Русская литература и культура между Востоком и Западом / редкол.: Ж. Хетени (отв. ред.), А. Дуккон, Ж. Калафатич. - Budapest, 2010. - С. 42-52.

24. Гофман М. Л. Последние дни Гоголя (новые материалы) // Руль. Берлин, 1925. - 25 января. - № 1260. - С. 2-3.

25. Гусев В. А. Трансформация гоголевского мифа в книгах «Духовный путь Гоголя» К. В. Мочульского и «Николай Гоголь» В. В. Набокова // Н. В. Гоголь и Русское Зарубежье: Пятые Гоголевские чтения: сб. докладов / Центральная городская библиотека - мемориальный центр «Дом Гоголя»; под общ. ред. В. П. Викуловой. - М.: Кн. дом «Университет», 2006. - С. 115-126.

26. Евтихиева А. С. Гоголь в критике Русского зарубежья: автореф. дис. ... канд. филол. наук / Московский гос. ун-т им. М. В. Ломоносова. M., 1999. - 24 c. 
27. Евтихиева А. С. Гоголь Русского зарубежья. - М.: Товарищество русских художников, 2001. - $144 \mathrm{c}$.

28. Евфимий (Моисеев), иеромонах. Значение исследователей Русского зарубежья в осмыслении духовного характера творчества Н. В. Гоголя // Духовная традиция в русской литературе: сб. науч. ст. / науч. ред., сост. Г. В. Мосалева. - Ижевск: Изд. дом «Удмуртский университет», 2009. - C. 63-73.

29. Ермишин О. Т. Н. В. Гоголь и эстетика В. В. Зеньковского (о принципах религиозной эстетики) // Н. В. Гоголь и Русское Зарубежье: Пятые Гоголевские чтения: сб. докладов / Центральная городская библиотека - мемориальный центр «Дом Гоголя»; под общ. ред. В. П. Викуловой. - М.: Кн. дом «Университет», 2006. - С. 217-221.

30. Есаулов И. А. Богословие и русская словесность: о. Георгий Флоровский о Гоголе // Н. В. Гоголь и Русское Зарубежье: Пятые Гоголевские чтения: сб. докладов / Центральная городская библиотека - мемориальный центр «Дом Гоголя»; под общ. ред. В. П. Викуловой. - М.: Кн. дом «Университет», 2006. - С. 222-228.

31. Жернакова Н. «Портрет» Гоголя в двух редакциях // Записки русской академической группы в США / ред. Н. А. Жернакова. - New York, 1984. - T. 17. - C. 23-47.

32. Зайцев Б. Жизнь с Гоголем // Современные записки. - Париж, 1935. № 59. - С. 272-287.

33. Записки русской академической группы в США / ред. Н. А. Жернакова. - New York, 1984. - Т. 17. - 321 с. На рус. и англ. яз.

34. Захаров К. М. К сюжету комедии Н. В. Гоголя «Владимир третьей степени»: о поэтике ненаписанного произведения // Филологические этюды: сб. науч. ст. молодых ученых. - Саратов, 2000. - Вып. 3. - С. 111-114.

35. Зеньковский В. В. История русской философии / сост. А. В. Поляков. Л.: Изд-во Эго, 1991. - Т. 1. - Ч. 1. - 222 с.

36. Злочевская А. Театр Н. В. Гоголя и драматургия Русского зарубежья первой волны // Вопросы литературы. - М., 2005. - № 2. - С. 209-235.

37. Ильин И. А. Гоголь - великий русский сатирик, романтик, философ жизни / пер. с нем. 3. Г. Антипенко // Ильин И. А. Собр. соч.: в 10 т. - М.: Русская книга, 1997. - Т. 6. - Кн. 3: О России и русской душе. - С. 240-276.

38. Каухчишвили Н. О художественных приемах у Гоголя // Записки русской академической группы в США / ред. Н. А. Жернакова. - New York, 1984. - T. 17. - С. 49-67.

39. Константин (Зайцев), игумен. Гоголь как учитель жизни // Сборник статей, посвященных памяти Н. В. Гоголя (1852-1952). - Буэнос-Айрес: Комитет Российской колонии в Аргентине, 1952. - С. 35-53.

40. Константин (Зайцев), игумен. Гоголь как учитель жизни // Духовный путь Н. В. Гоголя: в 2 ч. / авт.-сост. В. А. Воропаев, И. А. Виноградов. М.: Русское слово - РС, 2009. - Ч. 2: Гоголь в русской религиознофилософской критике. - С. 5-17. 
41. Крупич В. Гоголь и Аполлон Григорьев // Записки русской академической группы в США. Т. 17 / Ред. Н. А. Жернакова. - New York, 1984. С. $133-141$.

42. Моисеев Д. Н. В. Гоголь как писатель-христианин в оценке Русского зарубежья // Духовный мир: сб. работ учащихся Московских духовных школ. - Сергиев Посад, 1996. - Вып. 3. - С. 33-88.

43. Мочульский К. Духовный путь Гоголя // Мочульский К. Гоголь. Соловьев. Достоевский / сост. и послесл. В. М. Толмачева; примеч. К. А. Александровой. - М.: Республика, 1995. - С. 6-60.

44. Натова Н. Михаил Булгаков и Гоголь: Опыт сопоставительного анализа // Записки русской академической группы в США. Т. 17 / Ред. Н. А. Жернакова. - New-York, 1984. - С. 83-114.

45. Н. В. Гоголь и Русское Зарубежье: Пятые Гоголевские чтения: сб. докладов / Центральная городская библиотека - мемориальный центр «Дом Гоголя»; под общ. ред. В. П. Викуловой. - М.: Кн. дом «Университет», 2006. - 368 с.: ил.

46. Полнер Т. В. [Рец. на кн.: В. Вересаев. Гоголь в жизни] // Современные записки. - Париж, 1934. - № 56. - С. 430-432.

47. Полторацкий Н. И. А. Ильин о Гоголе // Записки русской академической группы в США. Т. 17 / под ред. Н. А. Жернакова. - New York, 1984. - С. 143-170.

48. Полторацкий Н. Ильин о Гоголе // И. А. Ильин. Жизнь, труды, мировоззрение. - Без м. изд. Эрмитаж, 1989. - С. 77-98.

49. Пророки Византизма: переписка К. Н. Леонтьева и Т. И. Филиппова (1875-1891) / сост., вступ. ст., подгот. текстов и коммент. О. Л. Фетисенко. - СПб.: Изд-во «Пушкинский Дом», 2012. - 728 с.: ил. (Сер. Русские беседы).

50. Сборник статей, посвященных памяти Н. В. Гоголя (1852-1952) = Serie de articulos en conmemoración del centenario del escritor ruso Nicolas Gogol (1852-1952). - Буэнос-Айрес: Комитет Российской колонии в Аргентине, 1952. - 208 с.

51. Сборник статей, посвященных памяти Н. В. Гоголя (1852-1952) = Serie de articulos en conmemoración del centenario del escritor ruso Nicolas Gogol (1852-1952). - Буэнос-Айрес: Русское слово, 1969. На обл. заглавие: «Великій Россіянинъ».

52. Словцов Р. [Калишевич Н. В.] [Рец. на кн.: В. Вересаев. Гоголь в жизни] // Последние новости. - Париж, 1933. - 13 июня.

53. Стихотворный альманах Н. В. Гоголя. Реконструкция замысла / подгот. текста и примеч. Е. М. Карповой, М. В. Строганова. - Тверь: СФК-офис, 2014. - 148 с.

54. Сугай Л.А.Гоголь и символисты: монография / ун-т им. Матея Бела (Словакия), фак. гуманитар. наук. - 2-е изд., испр. и доп. - Banská Bystrica: FHV UMB, 2011. - 524 с.: ил.

55. Террас В. «Шинель» Гоголя в критике молодого Достоевского // Записки русской академической группы в США. Т. 17 / Ред. Н. А. Жернакова. New York, 1984. - C. 75-81. 
56. Трудный Путь. Зарубежная Россия и Гоголь / сост., вступ. ст. и коммент. М. Д. Филина. - М.: Русскій Міръ, 2002. - 448 с.: ил.

57. Франк С. Л. Религиозное сознание Гоголя / пер. с нем. А. Г. Власкина // Франк С. Л. Русское мировоззрение. - СПб.: Наука, 1996. - С. 302-311.

58. Франк С. Л. Религиозное сознание Гоголя // Духовный путь Н. В. Гоголя: в 2 ч. / авт.-сост. В. А. Воропаев, И. А. Виноградов. - М.: Русское слово - РС, 2009. - Ч. 2: Гоголь в русской религиозно-философской критике. - С. 63-73.

59. Франк С. Л. Религиозное сознание Гоголя // Н. В. Гоголь: pro et contra: личность и творчество Н. В. Гоголя в оценке русских писателей, критиков, философов, исследователей: антология. - СПб.: Русская христианская гуманитарная академия, 2009. - Т. 1 / сост., вступ. ст. С. А. Гончарова, коммент. Н. Н. Акимовой и К. Г. Исупова. - С. 633-644.

60. Флоровский Г. В. Пути русского богословия / отв. ред. О. Платонов. М.: Институт русской цивилизации, 2009. - 848 с.

61. Хондзинский П., протоиерей. «Церковь не есть академия»: Русское внеакадемическое богословие XIX века / Православный Свято-Тихоновский гуманитарный ун-т. - М.: Изд-во ПСТГУ, 2016. - 480 с.

62. Хондзинский П. А., протоиерей. Н. В. Гоголь как представитель Laientheologie // Христианство и русская литература / отв. ред. В. А. Котельников и О. Л. Фетисенко. - СПб.: Изд-во «Пушкинский Дом», 2017. - С6. 8 - С. $68-86$.

63. Шлаин М. И. Противоречия в посылках и выводах (Ученые ФРГ о творчестве Гоголя) // Русская литература в оценке современной зарубежной критики / под ред. проф. В. И. Кулешова. - М.: Изд-во Московского ун-та, 1973. - С. 57-84.

64. Юрьева 3., Филипп В. О поэтике страха в повести Гоголя «Вий» // Записки русской академической группы в США / ред. Н. А. Жернакова. - New York, 1984. - T. 17. - C. 3-21.

65. Frank S. Nicolaj Gogol als religioser Geist // Hochland. 1934/1935. Bd. 1. - S. 251-259.

66. Gorlin M. N. V. Gogol und E. Th. A. Hoffmann. - Leipzig: Otto Harrassowitz Kommissionsverl., 1933. - $89 \mathrm{~s}$.

67. Setschkareff V. N. V. Gogol. Leben und Schaffen. - Berlin: Harrassowitz, 1953. - $192 \mathrm{~s}$.

68. Setchkarev V. Gogol: his life and works / transl. by Robert Kramer. - New York: New York University Press, 1965. - VII, 264 p. (The Gotham library)

69. Yurieff Z. Gogol as Interpreted by Russian Symbolists: A thesis presented by Zoya Yurieff to The Department of Slavic Languages and Literatures in partial fulfillment of the requirements for degree of Doctor of Philosophy in Subject of Slavic Languages and Literatures / Radcliffe College. - Cambridge, Massachusetts, 1955. - $329 \mathrm{p}$. 
70. Jakobson R., Aroutunova B. An unknown album page by Nikolaj Gogol // Harvard Library Bulletin. - 1972. - Vol. 20. - No. 3. - Pp. 236-254.

71. Jakobson R., Aroutunova B. An unknown album page by Nikolaj Gogol // Roman Jakobson selected writings / Edited, with a preface, by Stephen Rudy. - The Hague; Paris; New York: Mouton publishers, 1981. - Vol. 3: Poetry of Grammar and Grammar of Poetry. — Pp. 679-695.

Vladimir A. Voropaev

Lomonosov Moscow State University

(Moscow, Russian Federation)

voropaevvl@bk.ru

\section{Nikolai Gogol's Worldviews and Poetics in the Literary Criticism of the Russian Emigration (1921-2018)}

Acknowledgments. The reported study was funded by RFBR, project number 19112-50197.

Abstract. The Russian émigré community paid particular attention to Nikolai Gogol (possibly comparable only with Aleksandr Pushkin and Fyodor Dostoevsky). Themes and issues in Russian émigrés' studies of Gogol are highly diverse, although they predominantly focus on Gogol's poetics and religious views. Gogol and Dostoevsky, Gogol and Christian attitude to the laughter, Gogol's theater aesthetics, Gogol's progress as an author, rhythm in Gogol's prose, problem of the man in Gogol - these are the issues in Gogol's poetics have initially been posed by the literary critics in the Russian émigré community and subsequently developed by Russian scholars. Thanks to the works by Konstantin Mochulsky, Vasily Zenkovsky, Georgy Florovsky, Dmytro Chyzhevsky and Semyon Frank, it became possible to rebuff some deeply enrooted erroneous concepts of Gogol's personality. Gogol studies conducted in the Russian émigré community are an essential part of contemporary literary criticism. Despite limited sources, works by Russian émigré authors marked a new and essential stage in Gogol studies.

Keywords: Gogol, Russian Emigration, religious outlook, biography, poetics, interpretation, comic, terrible, rhythmic organization of the text, motif, intertext, album prose 
About the author: Voropaev Vladimir A. - Doctor of Philology, Professor of Department of History of Russian Literature, Lomonosov Moscow State University (Leninskie gory 1, Moscow, 119991, Russian Federation)

Received: July 20, 2020

Date of publication: October 30, 2020

For citation: Voropaev V. A. Nikolai Gogol's Worldviews and Poetics in the Literary Criticism of the Russian Emigration (1921-2018) In: Problemy istoricheskoy poetiki [The Problems of Historical Poetics], 2020, vol. 18, no. 4, pp. 138-163. DOI: 10.15393/j9.art.2020.8522 (In Russ.)

\section{References}

1. Averintsev S. S. Bakhtin, Laughter and Christian Culture. In: M. M. Bakhtin kak filosof [M. M. Bakhtin as a Philosopher]. Moscow, Nauka Publ., 1992, pp. 7-19. (In Russ.)

2. Aksakov K. S. A Few Words on Gogol's Poem: The Adventures of Chichikov, or Dead Souls. In: Aksakov K. S. Estetika i literaturnaya kritika [Aksakov K. S. Aesthetics and Literary Criticism]. Moscow, Iskusstvo Publ., 1995, pp. 74-85. (In Russ.)

3. Antoniy Surozhskiy, Mitropolit. Trudy: $v 2$ knigakh [Works: in 2 Books]. Moscow, Praktika Publ., 2012, book 1. 1112 p. (In Russ.)

4. Antonova M. S. Album Notes by Nikolai Gogol. In: Mir nauki, kul'tury, obrazovaniya [The World of Science, Culture, Education]. Gorno-Altaysk, 2019, no. 5 (78), pp. 514-515. (In Russ.) (a)

5. Antonova M. S. Nikolay Gogol's Note in M. Vlasova's Album: The Dating Problem. In: Litera. Moscow, 2019, no. 2, pp. 31-36. (In Russ.) (b)

6. Bakhrakh A. By Memory, by Notes. In: Novyy zhurnal [The New Review]. New York, 1993, no. 190/191, pp. 351-355. (In Russ.)

7. Beltrame F. The Unfinished Play "The Order of Vladimir, Third Class" as Gogol's Special Creative Laboratory. In: N. V. Gogol' i teatr: tret'i Gogolevskie chteniya: sbornik dokladov [N. V. Gogol and Theater: The Third Gogol Readings: Collection of Reports]. Moscow, Knizhnyy dom "Universitet', 2004, pp. 90-100. (In Russ.)

8. Botnikova A. B. Hoffmann and Gogol (Dialectical Perception of the Romantic Tradition). In: Botnikova A. B. E. T. A. Gofman i russkaya literatura (pervaya polovina XIX veka): $k$ probleme russko-nemetskikh literaturnykh svyazey [Botnikova A. B. E. T. A. Hoffmann and Russian Literature (the First Half of the 19th Century). More on the Problem of Russian and German Literary Relation]. Voronezh, Voronezh State University Publ., 1977, pp. 107-149. (In Russ.)

9. Weidlé V. M. Retsenziya na knigu M. Gorlina N. V. Gogol und E. Th. A. Hoffmann. O. Harrassowitz. Leipzig. 1933 [Review of M. Gorlin's Book N. V. Gogol und E. Th. A. Hoffmann. O. Harrassowitz. Leipzig. 1933]. In: Sovremennye zapiski. Paris, 1934, no. 54, p. 464. (In Russ.) 
10. Vinogradov I. A. Eschatology of the Comedy "The Government Inspector" by N. V. Gogol. In: Problemy istoricheskoy poetiki [The Problems of Historical Poetics], 2019, vol. 17, no. 4, pp. 68-90. Available at: https://poetica.pro/files/ redaktor_pdf/1571049477.pdf (accessed on May 30, 2020). DOI: 10.15393/ j9.art.2019.5801 (In Russ.)

11. Voropaev V. A. Gogol in Criticism of Russian Emigration. In: Russkaya literatura. St. Petersburg., 2002, no. 3, pp. 192-211. (In Russ.)

12. Voropaev V. A. Russian Emigration of N. V. Gogol. In: Russkaya rech'. Moscow, 2003, no. 2, pp. 16-21; no. 3, pp. 11-17; no. 4, pp. 10-18. (In Russ.)

13. Voropaev V. A. Gogol Nikolay Vasilievich (1809-1852). In: Literaturnaya entsiklopediya Russkogo zarubezh'ya. 1918-1940: $v 4$ tomakh [Literary Encyclopedia of the Russian Abroad. 1918-1940: in 4 Vols]. Moscow, Russian Political Encyclopedia Publ., 2006, vol. 4, pp. 95-117. (In Russ.)

14. Voropaev V. A. "To Die Singing..." Gogol's Prayer to the Blessed Virgin in Slavic Folklore and Literary Tradition. In: Problemy istoricheskoy poetiki [The Problems of Historical Poetics]. Petrozavodsk, Petrozavodsk State University Publ., 2016, issue 14, pp. 155-171. Available at: https://poetica.pro/ files/redaktor_pdf/1482826798.pdf (accessed on May 30, 2020). DOI: 10.15393/ j9.art.2016.3901 (In Russ.) (a)

15. Voropaev V. A. N. V. Gogol's Eschatology. In: Yazyk i tekst [Language and Text], 2016, vol. 3, no. 4, pp. 9-24. Available at: http://psyjournals.ru/langpsy/2016/n4/Voropaev.shtml (accessed on May 30, 2020). DOI: 10.17759/ langt.2016030402 (In Russ.) (b)

16. Voropaev V. A. N. V. Gogol and Patristic Heritage (to the Problem Statement). In: Vestnik Moskovskogo universiteta. Seriya 9. Filologiya [Moscow State University Bulletin. Series 9. Philology]. Moscow, 2017, no. 5, pp. 9-20. (In Russ.)

17. Voropaev V. A. "Ladder" of St. John of Sinai in the Life and Work of N. V. Gogol. In: Russkaya rech', Moscow, 2018, no. 6, pp. 101-108. (In Russ.)

18. Voropaev V. A. "Reflections on the Divine Liturgy" by N. V. Gogol in the Light of the Patristic Tradition. In: «Tainstvo slova i obraza»: $k$ 1030-letiyu Kreshcheniya Rusi: sbornik materialov nauchno-bogoslovskoy konferentsii ["The Sacrament of the Word and the Image": to the 1030th Anniversary of the Baptism of Rus: Collection of Materials of the Scientific and Theological Conference]. Sergiev Posad, Pereslavl, Moskovskaya dukhovnaya akademiya Publ., Izdatel'skiy otdel Pereslavskoy eparkhii Publ., 2019, pp. 264-279. (In Russ.)

19. Voropaev V. A. Gogol and Dobrotolyubie (to the Question Statement). In: Gogol' i russkaya dukhovnaya kul'tura. Devyatnadtsatye Gogolevskie chteniya: sbornik nauchnykh statey po materialam Mezhdunarodnoy nauchnoy konferentsii [Gogol and Russian Spiritual Culture. Nineteenth Gogol Readings: A Collection of Scientific Articles Based on the Materials of the International Scientific Conference]. Moscow, Novosibirsk, Novosibirskiy izdatel'skiy dom Publ., 2020, pp. 28-37. (In Russ.) 
20. Gogol' N. V. Polnoe sobranie sochineniy: $v 14$ tomakh [The Complete Works: in 14 Vols]. Leningrad, Academy of Sciences of the USSR Publ., 1952, vol. 8. 816 p. (In Russ.)

21. Gogol' N. V. Polnoe sobranie sochineniy i pisem: $v 17$ tomakh (15 knigakh) [The Complete Works and Letters: in 17 Vols (in 15 Books)]. Moscow, Kiev, Izdatel'stvo Moskovskoy Patriarkhii Publ., 2009-2010, vol. 6: Selected Places from the Correspondence with Friends. Spiritual Prose. Criticism. 744 p.; vol. 7: Youthful Experiences. First Redactions. 816 p.; vol. 9: Extracts from the Works of the Holy Fathers. Church Canons and Songs. Dictionaries. Notebooks. 968 p. (In Russ.)

22. Gol'denberg A. Kh. Hell and Paradise of Gogol (on the Problem of Interpreting the Writer's Work in the Criticism of the Russian Abroad. In: N. V. Gogol' $i$ Russkoe Zarubezh'e: Pyatye Gogolevskie chteniya: sbornik dokladov [N. V. Gogol and the Russian Abroad: The Fifth Gogol Readings: Collection of Reports]. Moscow, Knizhnyy dom “Universitet” Publ., 2006, pp. 89-101. (In Russ.)

23. Gol'denberg A. Kh. Eschatology Gogol as an Object of Critical Reflection Russian Literature Abroad. In: Gogol' i 20 vek: materialy Mezhdunarodnoy konferentsii, organizovannoy doktorskoy programmoy ELTE «Russkaya literatura i kul'tura mezhdu Vostokom i Zapadom» [Gogol and 20th Century. Proceedings of the International Conference Organized by the ELTE Doctoral Program "Russian Literature and Culture Between East and West"]. Budapest, 2010, pp. 42-52. (In Russ.)

24. Gofman M. L. Gogol's Last Days (New Materials). In: Rul'. Berlin, 1925, 25 January, no. 1260, pp. 2-3. (In Russ.)

25.Gusev V. A. The Transformation of the Gogol Myth in the Books "The Spiritual Path of Gogol" by K. V. Mochulsky and "Nikolai Gogol" by V. V. Nabokov. In: N. V. Gogol' i Russkoe Zarubezh'e: Pyatye Gogolevskie chteniya: sbornik dokladov [N. V. Gogol and the Russian Abroad: The Fifth Gogol Readings: Collection of Reports]. Moscow, Knizhnyy dom "Universitet" Publ., 2006, pp. 115-126. (In Russ.)

26. Evtikhieva A. S. Gogol'v kritike Russkogo zarubezh'ya: avtoref. dis. ... kand. filol. nauk [Gogol in Criticism of the Russian Abroad. PhD philol. sci. diss. abstract]. Moscow, 1999. 24 p. (In Russ.)

27. Evtikhieva A. S. Gogol' Russkogo Zarubezh'ya [Gogol of the Russian Abroad]. Moscow, Tovarishchestvo russkikh khudozhnikov Publ., 2001. 144 p. (In Russ.)

28. Evfimiy (Moiseev), hieromonk. The Value of Researchers of the Russian Abroad in Understanding of the Spiritual Nature of N. V. Gogol's Works. In: Dukhovnaya traditsiya $v$ russkoy literature: sbornik nauchnykh statey [Spiritual Tradition in Russian Literature: Collection of Scientific Articles]. Izhevsk, Udmurt State University Publ., 2009, pp. 63-73. (In Russ.)

29. Ermishin O. T. N. V. Gogol and V. V. Zenkovsky's Aesthetics (on the Principles of Religious Aesthetics). In: N. V. Gogol' i Russkoe Zarubezh'e: Pyatye Gogolevskie chteniya: sbornik dokladov [N. V. Gogol and the Russian Abroad: 
The Fifth Gogol Readings: Collection of Reports]. Moscow, Knizhnyy dom "Universitet" Publ., 2006, pp. 217-221. (In Russ.)

30.Esaulov I. A. Theology and Russian Literature: Fr. Georges Florovsky on Gogol. In: N. V. Gogol' i Russkoe Zarubezh'e: Pyatye Gogolevskie chteniya: sbornik dokladov [N. V. Gogol and the Russian Abroad: The Fifth Gogol Readings: Collection of Reports]. Moscow, Knizhnyy dom "Universitet" Publ., 2006, pp. 222-228. (In Russ.)

31. Zhernakova N. Two Versions of Gogol's "Portrait”. In: Zapiski russkoy akademicheskoy gruppy $v$ SShA [Notes of Russian Academic Group in USA]. New York, 1984, vol. 17, pp. 23-47. (In Russ.)

32.Zaytsev B. Life With Gogol. In: Sovremennye zapiski. Paris, 1935, no. 59, pp. 272-287. (In Russ.)

33.Zapiski russkoy akademicheskoy gruppy $v$ SShA [Notes of Russian Academic Group in USA]. New York, 1984, vol. 17. 321 p. (In Russ. and In English)

34.Zakharov K. M. To the Plot of Nikolai Gogol's Comedy "The Order of Vladimir, Third Class": on the Poetics of an Unwritten Work. In: Filologicheskie etyudy [Philological Etudes]. Saratov, 2000, issue 3, pp. 111-114. (In Russ.)

35.Zen'kovskiy V. V. Istoriya russkoy filosofii [History of Russian Philosophy]. Leningrad, Ego Publ., 1991, vol. 1, part 1. 222 p. (In Russ.)

36.Zlochevskaya A. Theatre of Gogol and Dramaturgy of Russian Literature Abroad of the First Wave. In: Voprosy literatury. Moscow, 2005, no. 2, pp. 209-235. (In Russ.)

37. Il'in I. A. Gogol - the Great Russian Satirist, Romantic, Philosopher of Life. In: Il'in I. A. Sobranie sochineniy: $v 10$ tomakh [Ilyin I. A. Collected Works in 10 Vols]. Moscow, Russkaya kniga Publ., 1997, vol. 6, book 3: About Russia and the Russian Soul, pp. 240-276. (In Russ.)

38. Kauchtschischwili N. On Artistic Techniques at Gogol. In: Zapiski russkoy akademicheskoy gruppy $v$ SShA [Notes of Russian Academic Group in USA]. New York, 1984, vol. 17, pp. 49-67. (In Russ.)

39. Konstantin (Zaytsev), Father Superior. Gogol as a Teacher of Life. In: Sbornik statey, posvyashchennykh pamyati N. V. Gogolya (1852-1952) [The Collection of Articles Sacred to the Memory of Nikolai Gogol (1852-1952)]. Buenos Aires, Komitet Rossiyskoy kolonii v Argentine Publ., 1952, pp. 35-53. (In Russ.)

40. Krupich V. Gogol and Apollon Grigoriev. In: Zapiski russkoy akademicheskoy gruppy v SShA [Notes of Russian Academic Group in USA]. New York, 1984, vol. 17, pp. 133-141. (In Russ.)

41. Konstantin (Zaytsev), Father Superior. Gogol as a Teacher of Life. In: Dukhovnyy put' N. V. Gogolya: $v 2$ chastyakh [The Spiritual Way of N. V. Gogol: in 2 Parts]. Moscow, Russkoe slovo - RS Publ., 2009, part 2: Gogol in Russian Religious and Philosophical Criticism, pp. 5-17. (In Russ.)

42.Moiseev D. N. V. Gogol as a Christian Writer in the Assessment of the Russian Abroad. In: Dukhovnyy mir: sbornik rabot uchashchikhsya Moskovskikh dukhovnykh shkol [Spiritual World: Collection of Works by Students of Moscow Theological Schools]. Sergiev Posad, 1996, issue 3, pp. 33-88. (In Russ.) 
43. Mochul'skiy K. Spiritual Path of Gogol. In: Mochul'skiy K. Gogol'. Solov'ev. Dostoevskiy [Mochulsky K. Gogol. Solovyov. Dostoevsky]. Moscow, Respublika Publ., 1995, pp. 6-60. (In Russ.)

44.Natova N. Mikhail Bulgakov and Gogol: The Experience of Comparative Analysis. In: Zapiski russkoy akademicheskoy gruppy $v$ SShA [Notes of Russian Academic Group in USA]. New-York, 1984, vol. 17, pp. 83-114. (In Russ.)

45.N. V. Gogol' i Russkoe Zarubezh'e: Pyatye Gogolevskie chteniya: sbornik dokladov [N. V. Gogol and the Russian Abroad: The Fifth Gogol Readings: Collection of Reports]. Moscow, Knizhnyy dom “Universitet” Publ., 2006. 368 p. (In Russ.)

46. Polner T. V. Retsenziya na knigu V. Veresaeva «Gogol' v zhizni» [Review of V. Veresaev's Book "Gogol in Life"]. In: Sovremennye zapiski. Paris, 1934, no. 56, pp. 430-432. (In Russ.)

47. Poltoratskiy N. I. A. Ilyin About Gogol. In: Zapiski russkoy akademicheskoy gruppy $v$ SShA [Notes of Russian Academic Group in USA]. New York, 1984, vol. 17, pp. 143-170. (In Russ.)

48. Poltoratskiy N. Ilyin About Gogol. In: I. A. Il'in. Zhizn', trudy, mirovozzrenie [I. A. Ilyin. Life, Works, Worldview]. Ermitazh Publ., 1989, pp. 77-98. (In Russ.)

49. Proroki Vizantizma: perepiska K. N. Leont'eva i T. I. Filippova (1875-1891) [Prophets of Byzantinism: Correspondence Between K. N. Leont'ev and T. I. Filippov]. St. Petersburg, Pushkinskiy Dom Publ., 2012. 728 p. (Ser. Russian Conversations). (In Russ.)

50. Sbornik statey, posvyashchennykh pamyati N. V. Gogolya (1852-1952) = Serie de articulos en conmemoración del centenario del escritor ruso Nicolas Gogol (1852-1952) [The Collection of Articles Sacred to the Memory of Nikolai Gogol (1852-1952)]. Buenos Aires, Komitet Rossiyskoy kolonii v Argentine Publ., 1952. 208 p. (In Russ.)

51. Sbornik statey, posvyashchennykh pamyati N. V. Gogolya (1852-1952) = Serie de articulos en conmemoración del centenario del escritor ruso Nicolas Gogol (1852-1952) [The Collection of Articles Sacred to the Memory of Nikolai Gogol (1852-1952)]. Buenos Aires, Russkoe slovo Publ., 1969. (In Russ.)

52. Slovtsov R. (Kalishevich N. V.). Retsenziya na knigu V. Veresaeva "Gogol' v zhizni" [Review of V. Veresaev's Book "Gogol in Life"]. In: Poslednie novosti. Paris, 1933, June 13. (In Russ.)

53. Stikhotvornyy al'manakh N. V. Gogolya. Rekonstruktsiya zamysla [Poetic Almanac of Gogol. Reconstruction of the Plan]. Tver, SFK-ofis Publ., 2014. 148 p. (In Russ.)

54.Sugay L. A. Gogol' i simvolisty [Gogol and the Symbolists]. Banská Bystrica, FHV UMB Publ., 2011. 524 p. (In Russ.) 
55. Terras V. Gogol's “The Overcoat” in Criticism of the Young Dostoevsky. In: Zapiski russkoy akademicheskoy gruppy $v$ SShA [Notes of Russian Academic Group in USA]. New York, 1984, vol. 17, pp. 75-81. (In Russ.)

56. Trudnyy Put'. Zarubezhnaya Rossiya i Gogol' [The Hard Way. Foreign Russia and Gogol]. Moscow, Russkiy Mir” Publ., 2002. 448 p. (In Russ.)

57. Frank S. L. Gogol's Religious Consciousness. In: Frank S. L. Russkoe mirovozzrenie [Frank S. L. Russian Worldview]. St. Petersburg, Nauka Publ., 1996, pp. 302-311. (In Russ.)

58. Frank S. L. Gogol's Religious Consciousness. In: Dukhovnyy put' N. V. Gogolya: $v 2$ chastyakh [The Spiritual Way of N. V. Gogol: in 2 Parts]. Moscow, Russkoe slovo - RS Publ., 2009, part 2: Gogol in Russian Religious and Philosophical Criticism, pp. 63-73. (In Russ.)

59. Frank S. L. Gogol's Religious Consciousness. In: N. V. Gogol': pro et contra: lichnost' i tvorchestvo N. V. Gogolya v otsenke russkikh pisateley, kritikov, filosofov, issledovateley: antologiya: $v 2$ tomakh [N. V. Gogol: Pro et Contra: Personality and Creativeness of Gogol in Opinion of Russian Writers, Critics, Philosophers, Researchers. Anthology: in 2 Vols]. St. Petersburg, the Russian Christian Academy for Humanities Publ., 2009, vol. 1, pp. 633-644. (In Russ.) 60. Florovskiy G. V. Puti russkogo bogosloviya [The Ways of Russian Theology]. Moscow, Institut russkoy tsivilizatsii Publ., 2009. 848 p. (In Russ.)

61. Khondzinskiy P., archpriest. "Tserkov' ne est' akademiya»: Russkoe vneakademicheskoe bogoslovie XIX veka ["The Church Is not an Academy": Russian Non-Academic Theology of the 19th Century]. Moscow, St. Tikhon's Orthodox University Publ., 2016. 480 p. (In Russ.)

62. Khondzinskiy P., archpriest. N. V. Gogol as a Representative Laientheologie. In: Khristianstvo i russkaya literatura [Christianity and Russian Literature]. St. Petersburg, Pushkinskiy Dom Publ., 2017, collection 8, pp. 68-86. (In Russ.)

63. Shlain M. I. Contradictions in Premises and Conclusions (German Scientists on the Works of Gogol). In: Russkaya literatura $v$ otsenke sovremennoy zarubezhnoy kritiki [Russian Literature in the Evaluation of Modern Foreign Criticism]. Moscow Moscow State University Publ., 1973, pp. 57-84. (In Russ.)

64.Yur'eva Z., Filipp V. On the Poetics of Fear in Gogol's Story “The Viy”. In: Zapiski russkoy akademicheskoy gruppy $v$ SShA [Notes of Russian Academic Group in USA]. New York, 1984, vol. 17, pp. 3-21. (In Russ.)

65. Frank S. Nicolaj Gogol als religioser Geist. In: Hochland, 1934/1935, vol. 1, pp. 251-259. (In German)

66. Gorlin M. N. V. Gogol und E. Th. A. Hoffmann [N. V. Gogol and E. Th. A. Hoffmann]. Leipzig, Otto Harrassowitz Kommissionsverlag Publ., 1933. 89 p. (In German)

67. Setschkareff V. N. V. Gogol. Leben und Schaffen [N. V. Gogol. Life and Work]. Berlin, Harrassowitz Publ., 1953. 192 p. (In German)

68.Setchkarev V. Gogol: His Life and Works. New York, New York University Press Publ., 1965. 264 p. (The Gotham Library). (In English) 
69. Yurieff Z. Gogol as Interpreted by Russian Symbolists: A Thesis Presented by Zoya Yurieff to The Department of Slavic Languages and Literatures in Partial Fulfillment of the Requirements for Degree of Doctor of Philosophy in Subject of Slavic Languages and Literatures. Cambridge, Massachusetts, 1955. 329 p. (In English)

70. Jakobson R., Aroutunova B. An Unknown Album Page by Nikolaj Gogol. In: Harvard Library Bulletin, 1972, vol. 20, no. 3, pp. 236-254. (In English)

71. Jakobson R., Aroutunova B. An Unknown Album Page by Nikolaj Gogol. In: Roman Jakobson Selected Writings. The Hague, Paris, New York, Mouton Publ., 1981, vol. 3: Poetry of Grammar and Grammar of Poetry, pp. 679-695. (In English) 